\title{
Bone - Graft Delivery Systems of Type PLGA-gentamicin and Collagen - hydroxyapatite - gentamicine
}

\begin{abstract}
OANA IONESCU (FILIP)ㄴ, MARIA VIORICA CIOCILTEU², COSTEL VALENTIN MANDA ${ }^{1}$, IONELA ANDREEA NEACSU², ANTON FICAI ${ }^{2}$, EMILIA AMZOIU ${ }^{1}$, ADINA TURCU STIO LICA ${ }^{1}$, OCTAVIAN CROITORU ${ }^{1}$, J OHNY NEAMTU ${ }^{1}$

'University of Medicine and Pharmacy of Craiova, Faculty of Pharmacy, 2 Petru Rares Str., 200638, Craiova, Romania 2University Politehnica of Bucharest, Faculty of Applied Chemistry and Materials Science,1-7 Polizu Str., 011061, Bucharest, Romania

The purpose of this study was the synthesis of two types of biodegradable materials with synthetic polymers (PLGA) or natural polymers (collagen) and hydroxyapatite, followed by determination of the encapsulation percentage of the drug in the polymer. Regardless of the chosen method, the percentage of the encapsulated drug was found to be quite high: 15.92\% in the Coll-HA-Genta material and 19.59\% respectively in the PLGAGenta biocomposite. The therapeutic value of gentamicin was improved by encapsulating it in delivery systems, contributing to sustained release for a long time (about 30 days).
\end{abstract}

Keywords: collagen-hidroxiapatite, PLGA-gentamicin, biocomposites, biodegradability

Physiological dynamics and remodeling pathways are essential to understanding bone kinetics during recovery as a result of trauma or reconstructive procedures [1].

Relevant information on the influence of the immune response on these events, with particular attention to tissue engineering and biomaterials, is reported, given their importance in the body [2,3]. Regardless of the application purpose, biomaterials have to fulfill two essential conditions: biofunctionality and biocompatibility $[4,5]$.

The field of biocomposite based on collagen and hydroxyapatite has been amazingly evolved over the last decades due to its remarkable features, being biomaterials very similar to the natural bone [6]. In this study, we will use third-generation bio-materials - because of their bioactive and bioresorbable properties that make the implanted material resorb over time, beeng replaced by newly formed tissue [7].

The research goal was to synthesize two types of composite materials (collagen-hydroxyapatite-antibiotic and PLGA-antibiotic) and to carry out a series of physicochemical characterizations (FT-IR, HPLC) in order to determine the loading capacity of the drug and in vitro release profile.

If the first polymer, collagen is part of the natural bone tissue along with hydroxyapatite, PLGA (polylactic-coglycolic acid) is part of the preferred biodegradable polymeric materials in the development of implantable devices and temporary implants as well as in pharmacological applications as vehicles for sustained release of a drug [8].

In order to include the antibiotic in the collagenhydroxyapatite composite material we used chemisorption while the inclusion of gentamicin in the PLGA microspheres was made by the solvent evaporation method: the water / oil / water double emulsion method $(\mathrm{A} / \mathrm{U} / \mathrm{A})$.

\section{Experimental part}

Materials and methods

Chemicals used in this study were of analytical grade: gentamicin - Fluka; PLGA- Merck; HPLC Water -
Synthesis of biocompatible systems

A. Synthesis of Collagen-Hydroxyapatite-Gentamicin (CollHA-Genta)

Synthesis of Collagen-Hydroxyapatite (Coll-Ha)

Synthesis of Coll-HA biocomposite consists of in-situ generation of hydroxyapatite in the collagen matrix. For this purpose a collagen-HA mixture was prepared with mass ratio 1: 1. The collagen used is stable in acid $\mathrm{pH}$, containing $2.26 \%$ pure (dry) substance. Thus, in a collagen mixture maintained at low temperatures (to prevent denaturation), a suspension containing $\mathrm{Ca}^{2+}$ ions is added dropwise, the mixture being stirred for 30 minutes at 400 rpm.

Subsequently, under careful temperature control, $\mathrm{a} \mathrm{PO}_{4}{ }^{3-}$ anion-generating suspension is gradually added, the mixture being maintained under mechanical stirring for another $30 \mathrm{~min}$ until the mixture is completely homogenized. The process is accompanied by HA precipitation directly into the collagen matrix. The inorganic precursors we used were $\mathrm{Ca}(\mathrm{OH})_{2}$, and $\left(\mathrm{NH}_{4}\right)_{2} \mathrm{HPO}_{4}$. The final blend we obtained had a white, viscous appearance. For cross-linking, a diluted solution of Glutaraldehyde ( $1 \%)$ was added to the mixture, then stored at $4^{\circ} \mathrm{C} / 24 \mathrm{~h}$. After cross-linking, the composite was washed with ultrapure water repeatedly until a neutral $\mathrm{pH}$ was established, then subjected to the lyophilization process. The gel thus obtained was subjected to the lyophilization process (freezing at $-55^{\circ} \mathrm{C}$ for $12 \mathrm{~h}$, vacuum at $0.001 \mathrm{mbar}$ for $12 \mathrm{~h}$ and heating under vacuum for $24 \mathrm{~h}$ to $35^{\circ} \mathrm{C}$ ) to obtain porous composite materials .

\section{Gentamicin addition by chemisorption}

In order to add gentamicin to the porous structure of the Coll-HA composite, a $4 \mathrm{mg} / \mathrm{mL}(10 \mathrm{~mL})$ aqueous drug solution was prepared. $50 \mathrm{mg}$ of Coll-HA were suspended in solution and maintained for 48 hours. After this time, the material was air-dried and the amount of cemisorbate drug was calculated by HPLC analysis.

B. Synthesis of PLGA-Gentamicin (PLGA-Genta)

For the synthesis of the biocompatible PLGA-gentamicin systems, the double dispersion $A_{1} / U / A_{2}$ method was used: 
the drug ( $15-150 \mathrm{mg}$ ) was solubilized in the aqueous phase $(0.4 \mathrm{~mL}$ of $0.5 \%$ PVA solution brought to $\mathrm{pH}=6$ with $0.1 \mathrm{M}$ sodium phosphate) then stirred at $45,000 \mathrm{rpm}$ with the oil phase represented by PLGA (100-200 mg) dissolved in 5 $\mathrm{mL}$ dichloromethane using a Silent Crusher vortex.

Obtaining the external aqueous phase $A_{2}$ was achieved by dissolving polyvinyl alcohol (APV) at $80-90$ degrees Celsius; Above it, the primary $A_{1} / U$ emulsion was added.

Evaporation of the stirring organic solvent at $500 \mathrm{rpm}$ was followed for $180 \mathrm{~min}$. The suspension obtained was subjected to a lyophilization process (freezing at $-45^{\circ} \mathrm{C}$ for $10 \mathrm{~h}$, vacuum at $0.014 \mathrm{mbar}$ for $12 \mathrm{~h}$ and heating under vacuum 0.014 mbar for $10 \mathrm{~h}$ at $20^{\circ} \mathrm{C}$ ) to obtain porous materials.

The biomaterials thus obtained were stored at $4{ }^{\circ} \mathrm{C}$ for later use.

\section{FT-IR characterization}

FTIR spectra were recorded using a Fourier Avatar Nicolet transformed spectrophotometer in potassium bromide in the range of $500-4000 \mathrm{~cm}^{-1}$.

Drug loading determination by HPLC-DAD

We used a Thermo Finnigan Surveyor HPLC System equipped with DAD detector and Thermo Finnigan Xcalibur data system with the following characteristics:

-Column: C18 reversed phase column (Thermo Scientific) Hypersil GOLD, $250 \mathrm{~mm} \times 4.6 \mathrm{~mm}$ I.D., particle size $5 \mu \mathrm{m}$.

- Mobile phase: acetonitrile: methanol: water (85:10:5), isocratic elution;

- Flow rate: $1 \mathrm{~mL} / \mathrm{min}$;

- Wavelength: $265 \mathrm{~nm}$;

\section{Calibration curve}

Stock solutions of gentamicin with concentration between $0-1 \mathrm{mg} / \mathrm{mL}$ were prepared by dissolving the drug in borat buffer ( $p H$ 9.7).

FMOC derivatization: $1 \mathrm{~mL} 30 \mathrm{mM}$ solution $\mathrm{FMOC}-\mathrm{Cl}$ in methanol was added over $2 \mathrm{~mL}$ gentamicin solution and 3 $\mathrm{mL}$ mobile phase. After $5 \mathrm{~min}$, the samples were filtered through 0.45 filter paper and $200 \mu \mathrm{L}$ were injected in the HPLC system.

\section{Samples}

Coll-HA-gentamicin

The quantity of chemisorbed gentamicin was determined by measuring the gentamicin amount in 0.5 $\mathrm{mL}$ solution before and after Coll-HA addition.

\section{PLGA-gentamicin}

$5 \mathrm{mg}$ PLGA-gentamicin composite was left with $1 \mathrm{~mL}$ borat buffer, $p \mathrm{H}=10$, for $24 \mathrm{~h}$ in order to hydrolyze the polymer.

$0.25 \mathrm{~mL}$ of the hydrolyzed solution was filtered through a $0.45 \mu \mathrm{m}$ porous membrane mixed with $0.75 \mathrm{~mL}$ borat buffer and $0.5 \mathrm{~mL}$ FMOC-Cl solution.

After $5 \mathrm{~min}, 200 \mu \mathrm{L}$ of this solution was injected into the chromatographic system.

The drug loading was calculated with the formula:

$$
\text { Drugloading }(\%)=\frac{\text { experimental gentamicin mass }(\mathrm{mg})}{\text { biocomositemass }(\mathrm{mg})} \times 100
$$

\section{In-vitro release profile}

In $5 \mathrm{~mL}$ of ultrapure HPLC water (LiChrosolv, Merck) 0.1 $\mathrm{g}$ of Coll-HA-Genta and PLGA-Genta were inserted, and the sealed flasks were kept in the oven at $37^{\circ} \mathrm{C}$ and were periodicallystirred.
At regular time intervals ( 1 day, 4 days, 10 days, 20 days, 30 days), $0.5 \mathrm{~mL}$ solution were taken for quantitative gentamicin determination by the above-described HPLC method. The removed volume was replaced with ultrapure water to avoid saturating the solution.

\section{Results and discussions}

Gentamicin is a small molecular weight drug $(477 \mathrm{~g} /$ mol) with good water solubility, precisely this hydrophilicity makes it not be able to be distributed in body fat and is minimally distributed in tissue fluids [9]; Administered IV or IM shows increased nephrotoxicity and ototoxicity. Gentamicin has been successfully used since 2011 by impregnation in bone cement in the treatment of infections in articular arthroplasty [10];

The local delivery of gentamicin in the treatment of osteomyelitis has been developed in the last decade both for prophylactic treatment and for infectious treatment, but using non-biodegradable polymers such as polymethylmethacrylate (PMMA) or calcium sulphate [11];

\section{FT-IR characterization of PLGA-Genta and Coll-HA-Genta}

In pure gentamicin, the amide groups were observed at $1618 \mathrm{~cm}^{-1}$ and $1508 \mathrm{~cm}^{-1}$ [12]. In both PLGA-Genta and Coll-HA-Genta the peaks for those groups were shifted to the right [13] suggesting some interactions between components. In all the spectra we observed in the region 2750-3450 $\mathrm{cm}^{-1}$ broad band corresponding to hydroxyl groups from gentamicin sulphate structure [14]. The peack at $1118 \mathrm{~cm}^{-1}$ in PLGA-Genta spectrum appear shifted to the right in PLGA-Genta and was attributed to the unreacted -OH groups prom the polymer [15].

\section{Synthesis of PLGA-Genta and Coll-HA-Genta and gentamicin determination by $H P L C$}

The PLGA-Genta synthesis method was chosen taking into account the hydrophilicity of gentamicin [16], in line with other articles [17]. The copolymer having a $65: 35$ ratio of monomers has a degradation time of about 4 months and a drug release time of 30-60 days [18].

Regarding the described HPLC method, gentamicin is a mixture of compounds isolated from Micromonospora purpurea, which do not absorb in the UV-Vis domain and therefore require derivatization with FMOC. As can be seen in the chromatogram of a standard $0.5 \mathrm{mg} / \mathrm{mL}$ solution, gentamicin exhibits four peaks characteristic of the main four gentamicin compounds (fig. 2A). The amount of FMOC-Cl required to react with gentamicin was calculated by knowing that each primary or secondary amino group reacted with a FMOC-Cl molecular fragment. Gentamicin also has three other glycosidic groups in the structure that

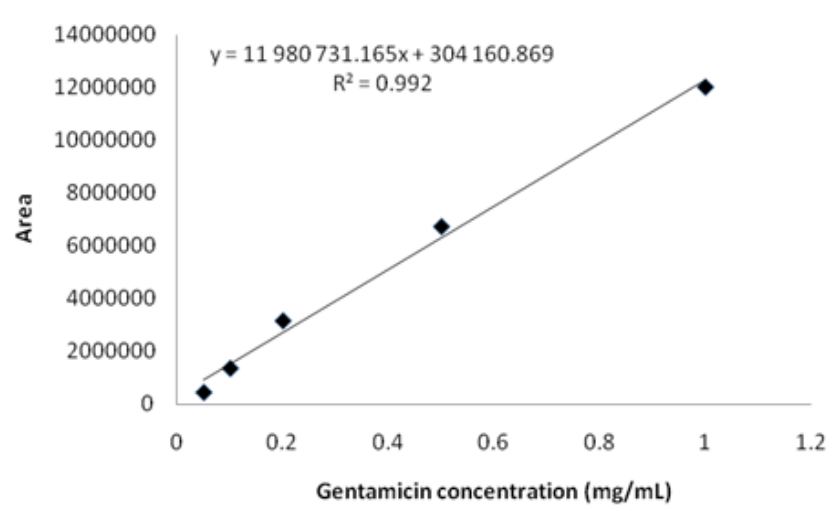

Fig.1. The calibration curve obtained for the fourth characteristic peak of the four compounds found in gentamicin , chosen for quantification 
1

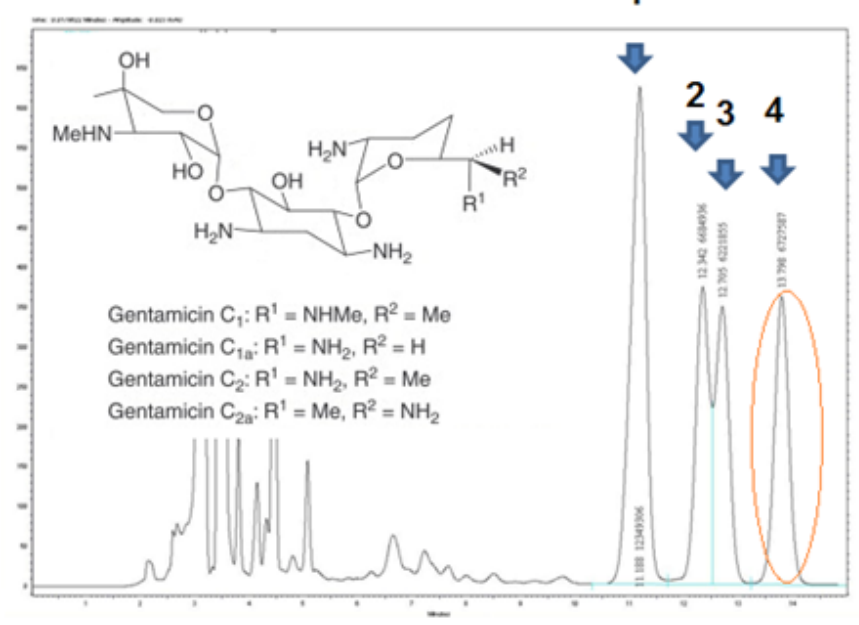

A

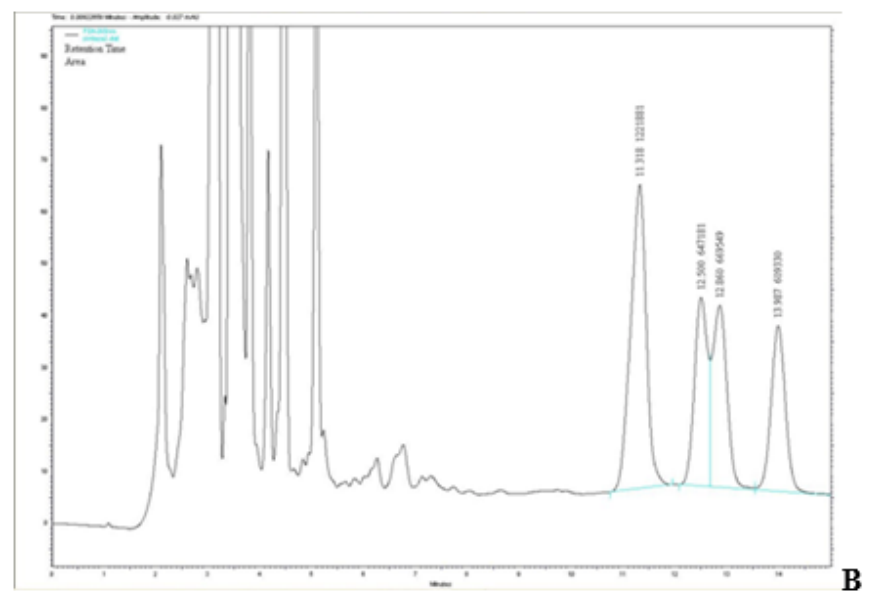

Fig. 2. A) Chromatogram of a standard solution of gentamicin $0.5 \mathrm{mg} / \mathrm{mL}$; B) PLGA-Genta (synthesis 2) chromatogram, diluted 1: 4

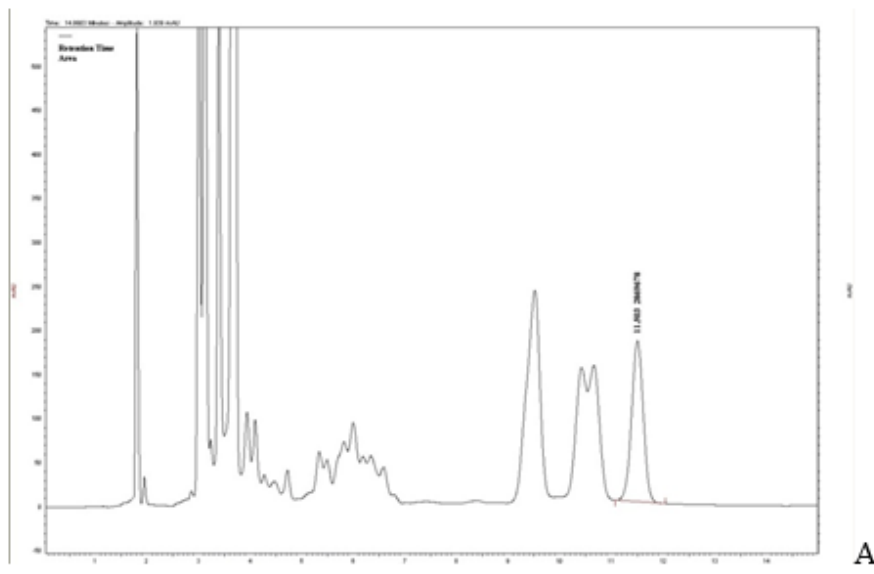

A

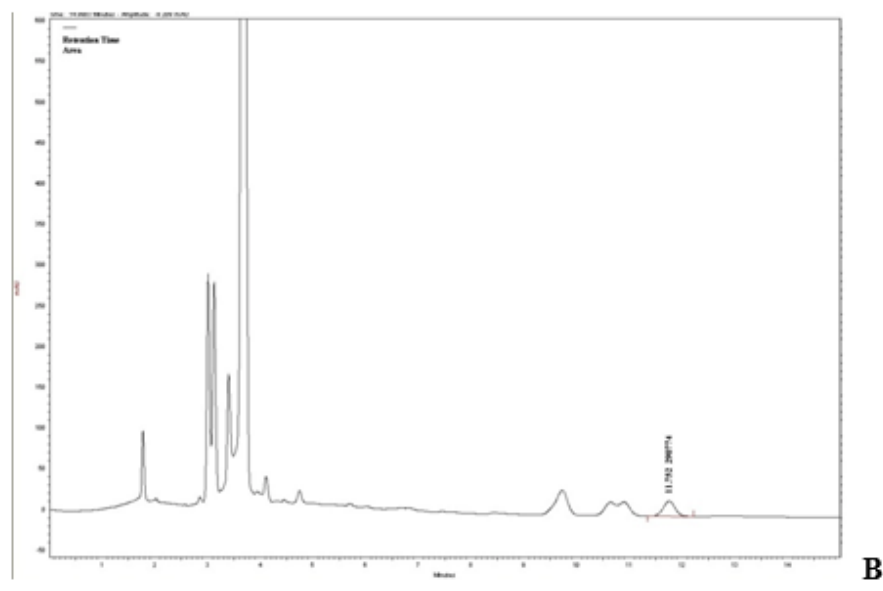

also react at neutral $\mathrm{pH}$ with the derivatizing agent. By working at a basic $\mathrm{pH}$, the additional reaction of amino glycoside OH groups with FMOC-Cl is stopped [19, 20].

By comparing the quantities of encapsulated drug using different amounts of PLGA, we obtained a higher degree of encapsulation for smaller amounts of polymer, probably due to the different porosity of the material (table 1).

Table 1

GENTAMICIN LOADED ON PLGA MICROPRTILCLES IN DIFFERENT EXPERIMENTAL CONDITIONS

\begin{tabular}{|c|c|c|r|}
\hline Sample & $\begin{array}{c}\text { Gentamicină } \\
(\mathbf{m g})\end{array}$ & $\begin{array}{c}\text { PLGA } \\
(\mathbf{m g})\end{array}$ & $\begin{array}{c}\text { Drug loading } \\
(\mathbf{\%})\end{array}$ \\
\hline Synthesis 1 & 10 & 100 & $6.3 \pm 0.4$ \\
\hline Synthesis 2 & 150 & 100 & $19.593 \pm 0.2$ \\
\hline Synthesis 3 & 10 & 200 & $3.539 \pm 0.2$ \\
\hline Synthesis 4 & 150 & 200 & $12.781 \pm 0.3$ \\
\hline
\end{tabular}

\section{Coll-HA-Genta}

By calculating the amount of gentamicin in the Coll-HAGenta composite, a significant percentage of $15.92 \%$ gentamicin was obtained. Considering that in this case the method of adding the drug to the porous structure of collagen was a chemisorption process, the immersion time of Coll-HA in the drug solution was limited to 48 hours so that the desorption process does not appear.

The percentage obtained is similar to that obtained by other methods of binding the hydroxyapatite to the drug such as adding the drug during the hydroxyapatite synthesis process by wet precipitation [21]. A major possible contribution to the high percentage of drug that can bind to the composite is also the porosity of the composite (due to the presence of collagen), porosity which implicitly leads to an increase in the contact surface.
A

Fig.3. A) Chromatogram of gentamicin solution before chemisorption; B) Chromatogram of gentamicin solution after chemisorptions, dilution factor $1: 2$ 


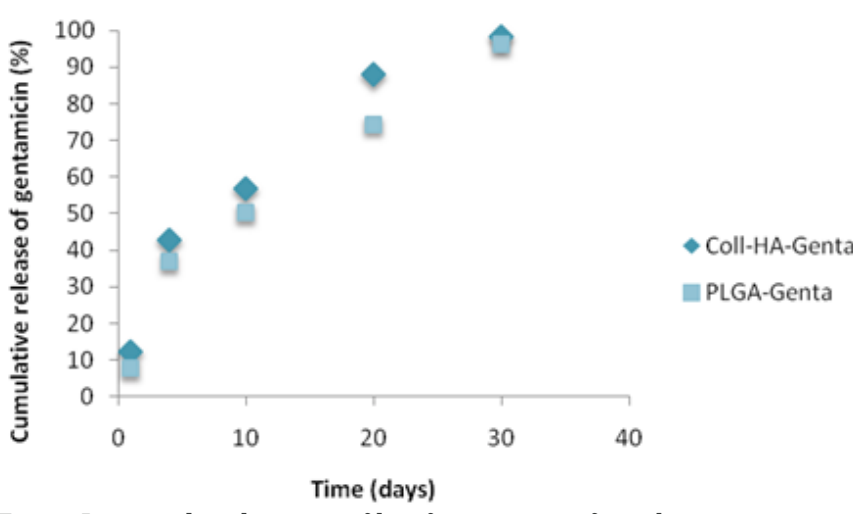

Fig. 4. In vitro dissolution profile of gentamicin from biocomposite

In-vitro release profile

In figure 4 is presented the in vitro release kinetics for PLGA-Genta and Coll-HA-Genta.

The release profile showed a burst release [22] in the first 10 days (56,78\% from Coll-HA-Genta and $50.22 \%$ from PLGA-Genta), followed by a sustained release for a long period of time (at 30 days $98.33 \%$ of gentamicin was released from Coll-HA-Genta and $9.23 \%$ from PLGAGenta), with a drug concentration capable of providing bactericidal activity.

The high percent (and also high concentration of gentamicin) obtained in the first 10 days helps prevent and treat post-surgical infections, when the risk of developing such an infection is maximal. The slow controlled release in the 10-30 days interval can be explained by the diffusion process, the drug embedded inside the polymer diffuse over a long distance compared with the distance it has to diffuse in the first 10 days. The the degradation of PLGA in time helps to obtain a controlled release also.

\section{Conclusions}

In this study, we succeeded the synthesis of two biocomposite materials PLGA-Genta and Coll-HA-Genta. The presence of antibiotic in large quantities in the two materials ensures local delivery of gentamicin in the prophylactic and infectious treatment of osteomyelitis, the most common bone infection occurring in orthopedic interventions. The in vitro gentamicin release showed a slow release profile over a long period of time (30-40 days) consistent with our purpuses of developing controlled gentamicin release composites.

\section{References}

1. OPRI, M., AMZOIU, E., MANOLEA, H., RICA, R., Key Eng Mater., 695, 2016, p.59
2.TURCU STIOLICA, A., BUBULICA, M.V., NICOLAESCU, O.E., CROITORU, O., POPESCU, M., MANDA, V.C., SIMIONESCU, A., NEAMTU, J., Rev.Chim.(Bucharest), 69, no.8, 2018, p.1944

3. NEAMTU, J., BUBULICA, M.V., ROTARU, A., DUCU, C., BALOSACHE, O.E., MANDA, V.C, TURCU-STIOLICA, A., NICOLICESCU, C., MELINTE, R., POPESCU, M., CROITORU, O., J Therm Anal Calorim., 127, 2017, p. 1567

4. MOCANU, A.G., TURCU STIOLICA, A., BELU, I., CIOCILTEU, M.V., MANDA, V.C., NICOLICESCU, C., NEAMTU, J., Rev.Chim.(Bucharest), 69, no. 6, 2018, p. 1132.

5. CIOCILTEU, M.V., MOCANU, A.G., MOCANU, A., DUCU, C., NICOLAESCU, O.E., MANDA, V.C., TURCU-STIOLICA A, NICOLICESCU C., MELINTE, R., BALASOIU, M., CROITORU, O., NEAMTU, J., Acta Pharm., 68, nr. 2, 2018, p. 129

6. VISSER, R., ARRABAL, P.M., BECERRA, J., RINAS, U., CIFUENTES, M., Biomater., 30, nr. 11, 2009, p. 2032.

7. CHAISRI, W., HENNINK, W.E., OKONOGI, S., Curr Drug Deliv., 6, 2009; p. 69

8. NIE, H., LEE, L.Y., TONG, H., WANG, C., J Control Release., 129, 2008, p. 207

9. BORDE, J., SUDKAMP, N.P., KONSTANTINIDIS, L., Int Orthop., 38, 2014, p.1077..

10. NEUT, D., DIJKSTRA, R.J .B., THOMPSON, J.I., VAN DER MEI, H.C., BUSSCHER, H.J., J Orthop Res., 29, 2011, p.1654

11. KLEMM, K., SCHNETTLER, R., Acta Orthop Belg., 58, 1992, p. 222 12. SINGH, M.P., STEFKO, J., LUMPKIN, J.A., ROSENBLATT, J., Pharm. Res., 12, 1995, p. 1205

13. SIONKOW SKA, A., KACZMAREK, B., GADZALA-KOPCIUCH, R., J. of Drug Deliv. Science and Technol., 35, 2016, p. 353

14. ARMENTANO, M., DOTTORI, E., FORTUNATI, S., MATTIOLI, J.M., Polym. Degrad. Stab., 95, nr. 11, 2010,, p. 2126

15. ZHANG, Y., ZHANG, M., J. Biomed. Mat. Res. A., 62, 2002, p. 378. 16. RAMAZANIA, F., CHENA, W., VAN NOSTRUMA, F., STORMA, G., KIESSLINGB, F., LAMMERS, T., HENNINKA, W.E, KOKA, R.) . Int J. of Pharma., 499, 2016, p.358

17. FLORES, C., DEGOUTIN, S., CHAI, F, RAOUL, G., HORNEZ, J.C., MARTEL, B., SIEPMANN, J., FERRI, J., BLANCHEMAIN, N., Mater. Sci. and Eng., C. 64, 2016, p. 108

18. ALEXIS, F., Polym Int., 54, 2005, p.36

19. KOROS, A., HANCZKO, R., JAMBOR, A., QIAN, Y., PERL, A., MOLNAR-PERL, I., J Chromatogr A. 1149, nr.1, 2007, p.46

20. GAO, C.X., KRUL, I.S., TRAINOR, T., J. Chrom. Sci., 28, 1990; p. 102

21. SINGH M.P., STEFKO, J., LUMPKIN J .A., ROSENBLATT, J., Pharm. Res., 12, 1995, p.1205

22. ROSCA, I.D., WATARI, F., UO, M., J. Control. Release, 99, 2004, p. 271.

23. GASPARINI, G., HOLDICH, R.G., KOSVINTSEV, S.R., Colloids Surf. B Biointerfaces, 75, 2010, p. 557

Manuscript received: 16.06 .2019 